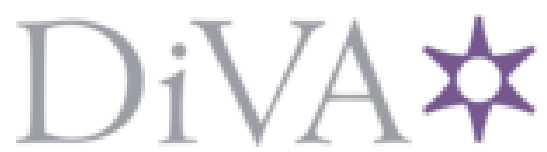

http://www.diva-portal.org

This is the published version of a chapter published in Visions of North in premodern Europe.

Citation for the original published chapter:

Jørgensen, D., Langum, V. (2018)

Envisioning North from a premodern perspective

In: Dolly Jørgensen and Virginia Langum (ed.), Visions of North in premodern Europe (pp. 1-11). Brepols

Cursor Mundi

https://doi.org/10.1484/M.CURSOR-EB.5.114054

N.B. When citing this work, cite the original published chapter.

Permanent link to this version:

http://urn.kb.se/resolve?urn=urn:nbn:se:umu:diva-143117 


\title{
ENVISIONING NORTH FROM A PREMODERN PERSPECTIVE
}

\author{
Dolly Jørgensen and Virginia Langum
}

I

$\mathrm{n}$ The Making of Europe, the medieval historian Robert Bartlett argues that 'Europe is both a region and an idea.' The same can be said of the North. The North is both a geographical region and an imaginative concept that varies, transforms, and coheres diachronically and synchronically according to the perspective adopted. Thus, North is a cardinal direction, but more importantly it is 'an overriding metaphor, a kind of culturally defined and maintained structuring principle that helps - literally like the compass itself - to orient ourselves in the world.'

North appears as this type of orienting direction in some of the earliest European literature when it serves to mark the opposite of Mediterranean warmth and temperance. ${ }^{3}$ In this view, cold comes forth from the North where

${ }^{1}$ Bartlett, The Making of Europe, p. 1.

${ }^{2}$ Fjaggesund, The Dream of the North, p. 16.

${ }^{3}$ In the modern era, writers like Viljhalmur Stefansson have constructed a vision of the Arctic as a 'polar mediterranean' that is a highly fertile and connected European space. Such constructions, while seemingly breaking down the otherness of the North, reify the implict ancient Greek and Roman idea that Mediterranean civilizations are the one and only European cultural model. See Steinberg, 'Europe's “Others” in the Polar Mediterranean'.

Dolly Jørgensen is professor of history at the Department of Cultural Studies and Languages at University of Stavanger.

Virginia Langum is associate professor of English literature at the Department of Language Studies at Umeå University and Pro Futura Scientia Fellow at the Swedish Collegium for Advanced Study at Uppsala University.

Visions of North in Premodern Europe, ed. by Dolly Jørgensen and Virginia Langum, CURSOR 3 I (Turnhout: Brepols, 2018) pp. 1-11 BREPOLS PUBLISHERS 10.1484/M.CURSOR-EB.5.114054 
it is born. The North sends bitterly cold wind and hurricane-strength gales that Ulysses must face. ${ }^{4}$ Many ancient writers imagined this cold climate as a land of desolation. When Pliny the Elder divided the earth into five zones, the northern and southern polar zones with their 'severe cold and perpetual frost' are contrasted with the temperate zones fit for civilization. ${ }^{5}$ Herodotus believed that continuous snowfall in the north led it to be uninhabited. ${ }^{6}$

Yet North has never been a singular direction or conception. While the views of Pliny and Herodotus align with our contemporary mental images of North as the land of cold, snow, and polar bears starving because of climate change, other premodern writers and image-makers drew upon a variety of visions of the North - from the land of perpetual sunshine to the land of great darkness, from the birthplace of civilization to the abode of evil. Contradictory images appear in the earliest ancient descriptions of the northern lands of the Hyperboreans and Thule, which are places of both light and darkness. Narratives of North in late antique and medieval writing invoke it as both the birthplace of Europe and source of barbarian destruction. North is located at the intersection of the sensible and the symbolic. Images of North draw from the material experiences of the far northern hemisphere: in far northern Scandinavia, the sun does not set in the summer and does not peek above the horizon in the winter, reindeer wander the northern landscape, and whales breech in the cold waters. But how writers interpret these phenomena - with wonder or fear, admiration or hatred - depends upon particular cultural frames.

The map by Olaus Rudbeck showing the Baltic Sea as the allegorical figure Charon on this book's cover is an example of a multi-layered North. In Greek myth, the ferryman Charon carries souls across the river Styx from the world of the living to the world of the dead. Rudbeck transported and reinterpreted this ancient Greek persona as North; the water becomes the body of Charon rather than a thing he crosses over. As discussed in the last chapter in this collection, Rudbeck was well known for this kind of juxtaposition of ancient myth onto northern geography: he re-envisioned the North through ancient Greek myths, arguing that astronomy had been invented by a Swedish king Atle who become known as Atlas, and that Sweden was the lost Atlantis. Rudbeck's image of Baltic Sea as Charon embodies conglomerate and contrasting visions of North.

\footnotetext{
${ }^{4}$ Homer, Odyssey, bks Ix, XIV, XIX.

${ }^{5}$ Pliny the Elder, The Natural History, II.68.

${ }^{6}$ Herodotus, The Histories, 4.31.
} 
The North as a circumpolar geographical and ideological space has received growing attention from humanities scholars interested in colonialism, imperialism, and environmental change. Yet curiously given these interests and their suggestive analogues in earlier cultures, modern scholarship and popular history have left the premodern North largely uncharted, instead almost exclusively mapping out the modern era. ${ }^{7}$ The premodern era has typically been incorporated into longer time period studies as the precursor of later ideas of North, such as in Peter Fjågesund's Dream of the North: A Cultural History to 1920 and Peter Davidson's The Idea of North. ${ }^{8}$ While these works partly redress the lack of reflection upon earlier cultural images and formations of the North as a concept, they focus on the period after 1700 .

The premodern North is, however, gaining traction as a space worth considering in its own right. Michael Pye's The Edge of the World, for example, focuses on the North Sea as culturally, economically, and politically formative in the history of medieval and early modern Europe. ${ }^{9}$ The recent edited volumes Imagining the Supernatural North and Travel in the North examine thematic practices of the premodern North, and additional studies investigate the geographical and cultural identity of particular northern regions in premodernity. ${ }^{10}$ Robert Rix's study The Barbarian North in Medieval Imagination probably comes closest to our intent of exploring the North as an envisioned, rather than physical, space with his analysis of 'out-of-Scandinavia' legends and their use in Anglo-Saxon texts. ${ }^{11}$

This collection contributes and expands the reach and understanding of premodern North by examining how North was envisioned by those living both inside and outside of northern spaces. For our purposes, North is more than arctic, but it is difficult to say where North begins on a map. Research shows that while North is related to geographical longitude, it is also a place that is

7 See, for example, Launius and others, Globalizing Polar Science; Jørgensen and Sörlin, Northscapes. The idea of Canada as a northern space has attracted the attention of many scholars, including Wynn, Canada and Arctic North America and Grace, Canada and the Idea of North.

${ }^{8}$ Fjågesund, The Dream of the North; Davidson, The Idea of North.

9 Pye, The Edge of the World.

${ }^{10}$ Barraclough and others, Imagining the Supernatural North; Gaupseth and others, Travels in the North. See, for example, Sobecki, The Sea and Medieval English Literature; Lavezzo, Angels on the Edge of the World.

${ }^{11}$ Rix, The Barbarian North in Medieval Imagination. 
'made' through cultural work from both insiders and outsiders. ${ }^{12}$ Rather than one thing, North is a space imagined by people, part of an identity, or state of mind, held not just by individuals but also by institutions, organizations, and societies.

This volume explores the idea of North from ancient times to the early modern period. As a collective, we are exploring where, who, and what was seen and defined as the European North over two millennia. The essays are all historically situated but approach their material from a variety of disciplines, including cultural history, literature studies, art history, environmental history, and history of science. Although the approaches are diverse, the primary sources used in the articles overlap significantly, including many that rely on the same histories, chronicles, travel writing, and maps, including the works of Pliny, Jordanes, Ranulph Higden, Olaus Magnus, and Jean Bodin.

\section{The Northness of North}

Although North is not one thing, recurring attributes bind together in order to give the North meaning. The North has been theorized as a 'culture of opposition', both from within and without. ${ }^{13}$ From within, residents of the North struggle against the climate and geography; they also wrestle with their own political identities. Outsiders exert influence in determining the relationship of North to the rest of Europe. Typically, such meaning-making often grounds itself in the Otherness of the North - it is defined in opposition to the South, specifically southern Europe, where ideas of civility became textually codified in the ancient period. ${ }^{14}$ Just as Edward Said stressed the role of defining East in opposition to West, North is established as distant and distinct from South. ${ }^{15}$ There is a tenacious grip of situated geographies on cultural conceptions and identities such as the West defined in opposition to the other. There is a relationship between the centre, taken to be the South in premodern Europe, and the periphery. Otherness can have both negative and positive attributes, leading to a complex meaning of the North as Other.

Not only do premodern authors 'other' the North in relation to the South, but they also tend to essentialize the North. As Edward Said notes, a geo-

12 Jørgensen and Sörlin, 'Making the Action Visible'.

13 Coates, 'The Discovery of the North'.

${ }^{14}$ Stadius, 'Southern Perspectives on the North'.

15 Said, Orientalism. 
graphical essentialism exists that assumes 'there are geographical spaces with indigenous, radically "different" inhabitants who can be defined on the basis of some religion, culture, or racial essence proper to that geographical space.'. ${ }^{16}$ While literary and artistic sources use various meanings and interpretations of North, ${ }^{17}$ there are commonalities. Daniel Chartier identifies a 'grammar of the idea of North' in modern literature, a list of recurring attributes and characteristics equated with North. These include character types such as Vikings, Inuits, and explorers; natural elements such as icebergs, polar bear, Northern Lights, and snow; and narratives such as physical exploration. ${ }^{18}$ These characteristics lend themselves to a general conceptualization of North as a mythical as well as geographical frontier. ${ }^{19}$ Likewise, North also serves to delimit bodies, interactions, characters, and various other traits. These essential northernly traits both shape Western European premodern writing and inform contemporary scholarly work.

While the essays in this collection focus on Western European writing, Western thinkers are certainly not the only premodern writers to theorize the North and northness. Scholars in both Eastern Europe and the Islamic world wrote extensively about who and what was in the North. The sixth-century Alexandrian scholar Cosmas Indicopleustes, for example, constructed a model of the Earth in which the sun revolved around a huge conical mountain in the North, resulting in night when the sun was behind the mountain. ${ }^{20} \mathrm{~A}$ newly edited collection of premodern Arabic travel writing demonstrates the intrigue and allure of the North. ${ }^{21}$ These early Arab writers offer early written accounts of settled Vikings in Russia, often using these barbarian people's cultural and religious practices as contrasts to the more 'civilized' practices of Islam. Similar to their Greek and Roman counterparts, Arabs envisioned the North as a land of eternal cold, snow, darkness, and desolation, yet experience told them that the land was also rich in culture, gold, and ingenuity. Throughout the essays in this volume, we encounter premodern texts that adopt and develop or contradict and question the concept of an othered or essentialized North.

${ }^{16}$ Said, Orientalism, p. 322.

17 See, for example, the essays in Jakobsson, Images of the North.

18 Chartier, 'Towards a Grammar of the Idea of North'.

19 Coates, 'The Discovery of the North', p. 23.

${ }^{20}$ Faller, 'The World According to Cosmas Indicopleustes', pp. 207-08.

${ }^{21}$ Ibn Fadlān, Ibn Fadlān and the Land of Darkness, ed. by Lunde. 


\section{Land of Contradiction}

The North, as an object of the southern gaze in premodern times, was a land of both known and unknown. Its epistemological status gave it great flexibility for interpretation and application. Indeed, we might say that the personality of the North was multiple and disordered, appearing as many different things to different groups over time, continuously interpreted and reinterpreted, confirmed and contradicted.

Early Greek literature invented the people who lived beyond (byper) the North Wind (Boreas), literally the Hyperboreans. Pär Sandin's examination of the literary appearances of these people reveals two potentially conflicting views about them: as wild horsemen of the Eurasian steppe and as the supernatural chosen people of Apollo. The two different visions of the Hyperboreans as people of the North are constructed, deconstructed, and reconstructed by each successive group of Greek writers to meet their own literary, political, or religious rationale.

In his chapter about the shifting classical definitions of the northern lands of Thule and Hyperborea, Lewis Webb shows how Northern otherness could serve as both positive and negative symbols of Roman aristocratic ambition. Thule was a mythical region or island north of Britain or Norway; Hyperborea was a land 'beyond the North Wind' where the sun shone twenty-four hours a day. Because Roman imperial ambition under Augustus appeared boundless, Virgil believed it would extend to the northern limits of Earth, to ultima Thule. But boundless desire was not always viewed in a positive light: Seneca criticized this trait as hubris and Lucan warned against being caught under the icy wagon of the Hyperborean Bear. The envisioned land of both ice and sun made an apt contradictory metaphor for Roman ambition.

The North, however, was more than metaphor in works of Roman geographers and historians. It was a place to be known and described, as shown in the chapter by Mirela Avdagic. Writers from the first century BCE to the sixth century CE knew that there was something in the North on the edge of civilization, whether that was called Thule, Hyperborea, or Scandza. They included these northern reaches in their geographical descriptions, creating layered meanings of contradictory elements such as islands and oceans, light and dark, uninhabited wastelands and organized tribes. The North was the beginning of classical civilization as the home of Apollo's mother and its end as the source of the barbarian invaders. For these geographers, North was a place construed by both map and myth.

Mythmaking features prominently in the history of the Northmen who settled in Normandy; the North was a foundational element of the identity politics 
of the settlers. As Barbara Auger argues in Chapter 4, the telling and retelling of where the early settlers of Normandy had come from created a place for the North in the South. Normandy became the land of men named for the North Wind, who brought with them a maritime cultural perception of the world. This sea-based view of the world was dynamic, rather than the static view from the land. The northern character of the Normans was both nature (dependent on the conditions of the North where they physically came from) and nurture (based on their cultural practices and maritime outlook). Creating a place for the North in the stories of the South also figures prominently in the analysis of Latin history writing in twelfth-century Norway as discussed by Steffen Hope in Chapter 5. Local Northern ecclesiastical culture, particularly the importance it placed on the Norwegian saint Olaf Haraldsson, affected how the North was portrayed in Latin literature written by Norwegian authors. These histories of the world connected the North with the larger Christian narrative, fitting the region into the accepted story.

In medieval and early modern medical thought, controversies emerged on whether Northness was a matter of nature or nurture. Virginia Langum argues that although traditional climate theory described extreme climates (hot and cold) as leading to uncivilized dispositions, English writers attempted to reformulate the effect of northern climes on personalities. While stereotypes of hot and cold complexions appear in prodigiously copied medieval texts like the encyclopaedia De proprietatibus rerum (On the Properties of Things) by Bartholomaeus Anglicus, negative characteristics such as wildness or stupidity do not map neatly onto cold climates.

Complex understandings of northern traits extended also to animals. The simultaneous wildness and domestication of the North are apparent in premodern perceptions of animals in the sea and on the land. As Vicki Szabo recounts, marine mammals - the monsters of the sea - were depicted in medieval and early modern texts sometimes as hyperbolic spectres and other times as practical resources. Whales evoked terror at sea, but when washed up on the shore they were eagerly harvested; they were many things at the same time. Whales were only one of the animals that came to represent North, as detailed in the contribution by Dolly Jørgensen. Premodern mapmakers populated their maps with animal life, but more than being random images, the animals placed in the North took on symbolic meaning. They declared that the North was both a place of wildness with wolverines and polar bears but also a place of domestication with reindeer and otters.

Geographies of the North factored into these portrayals of beastly Northness, an association which extended to human populations as well. The moun- 
tains of northern Britain and Scotland are not that far north on the map, but as Dawn Hollis reveals, they were symbolically another world for southern Englishmen. For Defoe, the north of Yorkshire was a wild but fruitful landscape; Scotland as north in contrast was a barren and sparse wilderness. Authors mapped these geographies onto people so that northern English were described as happy in spite of strange and quaint customs, whereas Scots were depicted as poor, lazy, and spiritually deficient. Giving people northern labels often had ideological consequences. As Jeremy DeAngelo explains in his contribution, English and Lowland Scots attempted to bolster their own 'southern' qualities by deliberately portraying the Highland Scots as northern heathens and sorcerers. In both word and image, the unruly populations of northern Scotland were envisioned as compatriots in arms and practice with the Sami of northern Scandinavia.

Drawing distinctions between peoples as northern or southern reified boundaries between the uncivilized and civilized. When writers in early modern Spain gazed to the North in the late sixteenth and early seventeenth century, they were looking through an opaque glass at a geographically and culturally remote region. Mateo Ballester Rodríguez argues that this created a vision of Scandinavia as a barbaric land full of fantastic phenomena, but direct contact in the later seventeenth century would change those portrayals. Italian views of North as the home of an evil wind stirring up the Reformation followed a similar trajectory. Helena Wangefelt Ström and Federico Barbierato argue that the North Wind, personified as Borea in the moral drama L'Oritia, was understood in Italy as both a physical and moral danger to civility. Just as Dante had envisioned the lowest circles of hell as icy cold rather than burning hot, the Northern cold had evil connotations. ${ }^{22}$

Early modern writers from within the North, as Kim Simonsen discusses in the case of the Faroe Islands, combated the outsiders' mystical visions of the North by focusing on the real natural wonders and indigenous sagas of the region. Their North was an object of curiosity rather than fear. North could even be an object of admiration according to Stefan Donecker's contribution. In works based on Jordanes, Scandinavia was envisioned as the 'womb of nations' - the wellspring of European civilization through its emigrants. Northern empowerment derived from a vision of barbarity leading to civility.

The visions and myths of the North have had a long-lasting hold on the imagination. This volume, which begins with the Greek and Roman idea of

${ }^{22}$ Davidson, The Idea of North, pp. 36-37. 
Thule and Hyperborea, ends with Olaus Rudbeck's seventeenth century reinterpretation of those myths as real Scandinavian places, discussed in Päivi Maria Pihlaja's chapter. Astronomers, naturalists, and philosophers used their early modern 'objective' sciences to posit a dynamic and ancient north.

However, premodern notions of the North outlasted premodernity. The concept of Thule as the birthplace of the Aryan race gained currency in the German mystical Thule Society in the late nineteenth and early twentieth centuries. $^{23}$ The appropriation of premodern myths formed a significant part of what has been called 'the Nazi supernatural imaginary. ${ }^{24}$ 'Thule' has been used to designate subsequent publications and musical groups aligned with Nazi political views. Many of these modern misappropriations build upon premodern notions of North.

The North as concept evokes both frisson and friction, particularly as deployed to draw borders around ideologies, traditions, and peoples, in some part due to its complex history. As this collection makes clear, the meaning of this demarcated North - whether positive or negative, shared or alien - and the grounds for making it - whether geographical, climatic, socio-cultural, ideological - is not monolithic but must be positioned in reference to particular texts and contexts. Nonetheless, the desire to locate, define, and describe the North and its contents appears as a consistent fascination for premodern storytellers, writers, and thinkers.

${ }^{23}$ McGhee, The Last Imaginary Place, p. 32.

${ }^{24}$ Kurlander, 'Hitler's Monsters'. 


\section{Works Cited}

\section{Primary Sources}

Herodotus, The Histories, trans. by Alfred Denis Godley (London: Heinemann, 1921-24) Homer, The Odyssey, trans. by Samuel Butler (London: Longmans, 1900)

Ibn Fadlān, Ibn Fadlān and the Land of Darkness: Arab Travellers in the Far North, ed. by Paul Lunde and Caroline Stone (London: Penguin, 2012)

Pliny the Elder, The Natural History, trans. by Henry T. Riley (London: Bohn, 1855)

\section{Secondary Works}

Barraclough, Eleanor Rosamund, Danielle Marie Cudmore, and Stefan Donecker, eds, Imagining the Supernatural North (Edmonton: University of Alberta Press, 2016)

Bartlett, Robert, The Making of Europe: Conquest, Colonization and Cultural Change, 950-1350 (London: Penguin, 1993)

Chartier, Daniel, 'Towards a Grammar of the Idea of North: Nordicity, Winterity', Nordlit: Arbeidstidsskrift i Litteratur, 22 (2007), 35-47

Coates, Kenneth, 'The Discovery of North: Towards a Conceptual Framework for the Study of Northern/Remote Regions', The Northern Review, 12/13 (1993/94), 15-43

Davidson, Peter, The Idea of North (London: Reaktion Books, 2005)

Faller, Stefan, 'The World According to Cosmas Indicopleustes - Concepts and Illustrations of an Alexandrian Merchant and Monk', Transcultural Studies 1 (2011), 193-232

Fjågesund, Peter, The Dream of the North: A Cultural History to 1920 (Amsterdam: Rodopi, 2014)

Gaupseth, Silje, Marie-Theres Federhofer, and Per Pippin Aspaas, eds, Travels in the North: A Multidisciplinary Approach to the Long History of Northern Travel Writing (Hannover: Wehrhahn, 2013)

Grace, Sherrill E., Canada and the Idea of North (Montreal: McGill-Queen's University Press, 2001)

Jakobsson, Sverrir, ed., Images of the North: Histories, Identities, Ideas (Amsterdam: Rodopi, 2009)

Jørgensen, Dolly, and Sverker Sörlin, 'Making the Action Visible-Environing in Northern Landscapes', in Northscapes: History, Technology, and the Making of Northern Environments, ed. by Dolly Jørgensen and Sverker Sörlin (Vancouver: University of British Columbia Press, 2013), pp. 1-14

—, eds, Northscapes: History, Technology, and the Making of Northern Environments (Vancouver: University of British Columbia Press, 2013)

Kurlander, Eric. 'Hitler's Monsters: The Occult Roots of Nazism and the Emergence of the Nazi “Supernatural Imaginary”, German History, 30.4 (2012), 528-49

Launius, Roger D., James Rodger Fleming, and David H. Devorkin, eds, Globalizing Polar Science: Reconsidering the International Polar and Geophysical Years (New York: Palgrave, 2010) 
Lavezzo, Kathy, Angels on the Edge of the World: Geography, Literature, and English Community (Ithaca: Cornell University Press, 2006)

McGhee, Robert, The Last Imaginary Place: A Human History of the Arctic World (Oxford: Oxford University Press, 2005)

Pye, Michael, The Edge of the World: How the North Sea Made Us Who We Are (London: Pegasus, 2014)

Rix, Robert W., The Barbarian North in the Medieval Imagination: Ethnicity, Legend, and Literature, Routledge Studies in Medieval Religion and Culture, 11 (London: Routledge, 2015)

Said, Edward W., Orientalism (New York: Vintage Books, 1979)

Sobecki, Sebastian I., ed., The Sea and Medieval English Literature (Cambridge: Brewer, 2008)

Stadius, Peter, 'Southern Perspectives on the North: Legends, Stereotypes, Images and Models', Baltic Sea Area Studies (BaltSeaNet) Working Paper, 3 (Berlin: BaltSeaNet, 2001)

Steinberg, Philip E., 'Europe's "Others" in the Polar Mediterranean', Tijdschrift voor Economische en Sociale Georgafie, 107 (2016), 177-88

Wynn, Graeme, Canada and Arctic North America: An Environmental History (Santa Barbara: ABC Clio, 2007) 